\title{
Effect of Potato virus $X$ on total phenol and alkaloid contents in Datura stramonium leaves
}

\author{
Lígia Maria Lembo Duarte ${ }^{1}$, Maria Luiza Faria Salatino ${ }^{2}$, Antonio Salatino ${ }^{2}$, Giuseppina Negri ${ }^{3}$, Maria Mércia \\ Barradas $^{1}$
}

\begin{abstract}
${ }^{1}$ Centro de Pesquisa e Desenvolvimento de Sanidade Vegetal, Instituto Biológico, Av. Cons. Rodrigues Alves, 1252, 04014-002; ${ }^{2}$ Institute of Biosciences, University of São Paulo, C.P. 11461, 05422-970, ${ }^{3}$ CEBRID, Universidade Federal de São Paulo, Rua Botucatu, 862, CEP 04023062, São Paulo, Brazil. E-mail: duarte@biologico.sp.gov.br

Corresponding author: Lígia Maria Lembo Duarte

Data de chegada:01/09/2005. Aceito para publicação em:02/10/2005

1248

\section{ABSTRACT}

Duarte, L.M.L.; Salatino, M.L.F.; Salatino, A.; Negri, G.; Barradas, M.M. Effect of Potato virus X on total phenol and alkaloid contents in Datura stramonium leaves. Summa Phytopathologica, v.34, n.1, p.65-67, 2008

The present paper reports results of the effect of Potato virus $X$ (PVX) on the contents of total phenols and alkaloids in leaves of Datura stramonium. A significant decrease in the contents of phenols and alkaloids was observed in leaves inoculated with PVX (X-I). However, there was an increase in the percentage of phenols in leaves rubbed with phosphate buffer (C1-I) and in leaves from the nodes immediately above, possibly induced by mechanical injury. Gas chromatography/mass spectroscopy revealed amounts of scopolamine

in samples submitted to all treatments, except X-I, in which the amount of this alkaloid was low. High amounts of an unidentified compound (molecular ion $\mathrm{m} / \mathrm{z} 302$ and a prominent peak at $\mathrm{m} / \mathrm{z} 129$ ) were noted in extracts from leaves X-I, C1-I and leaves from the nodes immediately above the leaves inoculated with PVX. It is suggested that the synthesis and accumulation of the unidentified compound is a result of stress from mechanical injury and virus inoculation.
\end{abstract}

Additional keywords: Potexvirus, phenolics, tropane alkaloids, medicinal plant

\section{RESUMO}

Duarte, L.M.L.; Salatino, M.L.F.; Salatino, A.; Negri, G.; Barradas, M.M. Efeito do Potato virus X no conteúdo de fenóis totais e alcalóides em folhas de Datura stramonium. Summa Phytopathologica, v.34, n.1, p.65-67, 2008

O presente trabalho relata resultados sobre a ação do Potato virus $X$ (PVX) no conteúdo de fenóis totais e alcalóides em folhas de Datura stramonium. Uma diminuição significativa no conteúdo dessas substâncias foi observada nas folhas inoculadas com o PVX (X-I). Entretanto, houve um aumento na porcentagem de fenóis nas folhas friccionadas com tampão fosfato (C1-I) e nas acima das friccionadas, possivelmente induzido por injúria mecânica. Cromatografia gasosa/espectroscopia de massas revelou quantidades de escopolamina nas amostras submetidas a todos os tratamentos, exceto em X-I, no qual a quantidade deste alcalóide foi baixa. Altas quantidades de uma substância não identificada (íon molecular $\mathrm{m} / \mathrm{z} 302$ e um proeminente pico a $\mathrm{m} / \mathrm{z} 129$ ) foram notadas em extratos a partir de folhas dos tratamentos X-I, C1-I e nas acima das inoculadas com o PVX. Sugere-se que a síntese e acúmulo da substância não identificada é um resultado do estresse causado pela injúria mecânica e pelo vírus.

Palavras chave: Potexvirus, substâncias fenólicas, alcalóides tropânicos, plantas medicinais

In general, the responses of plants to pathogen infections are characterized by metabolic changes associated to the development of the symptoms or to defense reactions $(6,15)$. Various physiological changes associated to viral infection have been studied such as: decrease in photosynthetic activity, increase in respiration rate, accumulation of nitrogen compounds, increase in polyphenoloxidase activity and alterations in hormonal and secondary metabolisms $(2,6)$.

Different classes of secondary compounds have been shown to exert a role of defense against pathogens and herbivores, such as alkaloids, cianogenic glycosides, glycosinolates, phenolic compounds and terpens (4). In this respect, the evaluation of the contents of phenolic substances is an aspect that has deserved much attention $(7,8)$.

As to alkaloids, some papers have reported alterations of the contents of tropane alkaloids $(3,13)$.

This paper deals with the effect of Potato virus $X(\mathrm{PVX})$ on the contents of total phenols and tropane alkaloids of Datura stramonium
L. (Solanaceae). It is worth mentioning that Potato virus $X(\mathrm{PVX})$ is of great economic importance to the potato crop because it is widely spread in producer regions of the world and presents high levels of infection causing significant losses in production of about $10 \%$ in simple infection and $60 \%$ when associated with Potato virus $Y$ (PVY) (12). The virus infects several species including D. stramonium, which is an important source of atropine (hyosciamine) and scopolamine (hyoscine) employed as sedatives, as well as antispasmodic and mydiatric agents $(9)$.

D. stramonium seeds were planted to obtain individuals growing in summer and winter so as to observe results at different temperatures and photoperiod conditions. Forty-five days after germination, leaves from the third and fourth node above the cotyledons were inoculated with PVX. The virus was mechanically inoculated by grinding $1 \mathrm{~g}$ of leaves from PVX infected Nicotiana tabacum "White Burley" in $3 \mathrm{~mL}$ of $0.01 \mathrm{M}$ phosphate buffer (PB), pH 7.0 and rubbing the extract onto the leaves. For controls, leaves were either PB-rubbed 
Table 1. Percentages of total phenols and alkaloids in PVX-infected and healthy leaves of Datura stramonium, and relative amounts of substances in alkaloidal extracts analyzed by GC/MS and evaluated by the intensity of the corresponding peaks.

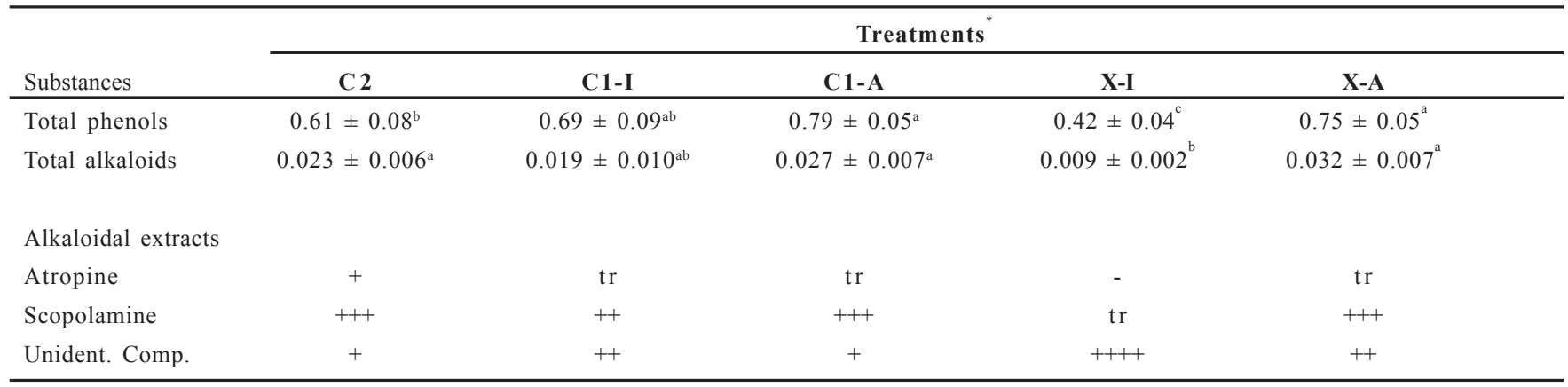

*C2 = untreated leaves, C1-I = phosphate buffer rubbed leaves, C1-A = leaves from nodes above leaves rubbed

with phosphate buffer, X-I = leaves inoculated with PVX, X-A = leaves from nodes above leaves inoculated with PVX, tr = trace; - = non detected. Same letters do not differ significantly at $5 \%$ by tukey test.

(C1-I) or were not submitted to any treatment (C2). Inoculated leaves (X-I) and leaves from nodes immediately above those submitted to either PB-rubbing (C1-A) or virus inoculation (X-A) were collected ten days after the corresponding treatment.

Total phenols extracts were obtained from C2, C1-I, C1-A, X-I and $\mathrm{X}$-A leaves. Extraction and evaluation procedures followed Phillips $\&$ Henshaw (10) with powdered leaves previously dried at $60^{\circ} \mathrm{C}$ until constant weight, using Folin-Denis reagent and measuring absorbances at $725 \mathrm{~nm}$ (5). Three independent evaluations were carried out in triplicates for each treatment. A calibration curve was prepared using aliquots of $0.1-1.0 \mathrm{~mL}$ of a $100 \mathrm{Pg} \mathrm{mL}^{-1}$ methanolic solution of tannic acid.

Alkaloids were extracted from leaves corresponding to all treatments described in the previous section. Extraction procedures followed Harborne (4), with modifications. Dried and powdered tissue $(1 \mathrm{~g})$ was extracted with $10 \%$ acetic acid in ethanol for $4 \mathrm{~h}$ at room temperature. The extract was made alkaline with the addition of $\mathrm{NH}_{4} \mathrm{OH}$, water was added and then chloroform was used to extract the alkaloids. The alkaloids were then extracted with $0.1 \mathrm{M}$ sulfuric acid, the aqueous extract was made alkaline with $\mathrm{NH}_{4} \mathrm{OH}$ and the alkaloids were extracted with chloroform. The solvent was evaporated under stream of $\mathrm{N}_{2}$. The residue was taken in $5 \mathrm{~mL}$ methanol and the absorbance was recorded at $207 \mathrm{~nm}$. Three independent evaluations were carried out in triplicates for each treatment. A calibration curve was prepared with methanolic solutions of atropine at $5-50 \mathrm{Pg} \mathrm{mL}^{-1}$.

The residue obtained by chloroform evaporation in the alkaloid extraction was dissolved in 10 PL of methanol, and 5 PL of this solution was injected in an HP gas chromatograph/mass spectrometer, using an HP Ultra- 1 capillary column $(25 \mathrm{~m} \times 0.32 \mathrm{~mm})$ and helium as a carrier gas at $1.5 \mathrm{~cm}^{3} \mathrm{~min}^{-1}$. Temperatures of the column were programmed starting at $100^{\circ} \mathrm{C}$ and increasing at $10^{\circ} \mathrm{C} \mathrm{min}{ }^{-1}$, followed by an isothermic period of $20 \mathrm{~min}$. The temperature of injector and detector was $300^{\circ} \mathrm{C}$. Identification of the compounds was achieved by comparison of retention times with an authentic sample of atropine and comparison of mass spectra with data from the Wiley275 library (Hewllet Packard). Relative amounts of individual compounds were estimated based on the intensities of the corresponding peaks.

Data obtained were analysed using Tukey test at $5 \%$ of probability. The original data were transformed in arcsen Öx/100.

In comparison with control $\mathrm{C} 2$, the contents of total phenols increased in C1-I, C1-A and X-A leaves but significantly decreased in $\mathrm{X}$-I leaves (Table 1). The higher percentages of total phenols in $\mathrm{C} 1-$
I, C1-A and X-A may be a consequence of the injury caused by the inoculation procedure that induced the synthesis of more phenolic compounds in response to mechanical injury. Such synthesis of stress compounds has been previously reported $(1,14)$.

The percentage of total phenols was decreased in X-I (table 1) when evaluated ten days after inoculation, the period corresponding to the maximum rate of replication under the conditions of this experiment (data not shown). It is worth mentioning that the $D$. stramonium leaves immediately above those inoculated with PVX (X-A) showed only mosaic symptoms, while the inoculated leaves themselves (X-I) showed both mosaic symptoms and necrotic spots. Legran et al. (7) reported a decrease in the phenolic compound levels in Nicotiana tabacum 'Samsun NN' with hypersensitive reaction. It is possible that the nutritional sources in the leaves with necrotic spots were lowered leading to a decrease in the percentage of these compounds.

The contents of total alkaloids also decreased in X-I leaves (Table $1)$. This agrees with the findings of other authors $(3,11)$, although most of them did not evaluate alkaloid contents in inoculated leaves separately from those of the nodes above. In relation to the other treatments, the contents in leaves did not significantly differ from the C2 control leaves (Table 1).

C2 leaves exhibited both atropine and scopolamine, with predominance of the latter. In addition, an unidentified substance with molecular ion $\mathrm{m} / \mathrm{z} 302$ and a prominent peak at $\mathrm{m} / \mathrm{z} 129$ (most probably not an alkaloid, because the $\mathrm{m} / \mathrm{z}$ value is an even number) was also detected (Table 1). The relative content of this substance was higher in $\mathrm{C} 1-\mathrm{I}$ and $\mathrm{X}-\mathrm{A}$, reaching the apparent lowest content in $\mathrm{C} 1-\mathrm{A}$; its maximum content was observed in X-I, which apparently contained no atropine and only traces of scopolamine. Leaves from other treatments yielded only traces of atropine. C1-A and X-A yielded higher amounts of scopolamine, even higher than $\mathrm{C} 2$ leaves. C1-I leaves contained lower amounts of scopolamine than C2 (Table1).

Nearly undetectable quantities of atropine and scopolamine by GC/MS were observed in X-I extracts, a result that agrees with spectrophotometric analysis. However, the unidentified substance appeared in relatively highest amounts in such leaves. The same substance was noted in alkaloidal extracts from C1-I and X-A treatments, which suggests that its synthesis is stimulated not only by mechanical injury, but also by stress caused by virus infection, since the substance appeared also in relatively high concentration in leaves from nodes above the rubbed leaves (X-A). Accumulation of stress compounds induced by viruses has also been reported in other 
virus-host systems (14). It is possible that the increased accumulation of the unidentified substance is not virus-specific, even though its highest content was observed in X-I leaves (Table1). Uegaki et al. (14) detected 19 sesquiterpenoids by GC/MS as stress compounds in leaves of Nicotiana undulata inoculated with Tobacco mosaic virus (TMV).

The decrease of phenols and alkaloid contents in inoculated leaves (X-I) is probably a consequence of a deviation in metabolic pathways, leading to an increase of the unidentified substance in the inoculated leaves. Another reason for the decrease of phenol and alkaloid contents could be a demand for synthesis of viral components, which would result in the host cells in competition with normal biosynthetic pathways for essential precursors (15).

It was noticeable that the results did not differ in the run of the whole year

The present paper provides data for the study of plant resistance to viral infection, and for a better understanding of the PVX-D. stramonium relation, especially in regard to the phenolic compounds and alkaloids which can be evolved in plant defense.

\section{ACKNOWLEDGMENTS}

The authors thank CNPq (Conselho Nacional do Desenvolvimento Científico e Tecnológico) and FAPESP (Fundação de Amparo à Pesquisa do Estado de São Paulo) for providing funds partly used to carry out this research, and to Mr John Norman for critical reading the manuscript.

\section{REFERENCES}

1. Balogun, O. S.; Teraoka, T. Time-course analysis of the accumulation of phenols in tomato seedlings infected with Potato virus $X$ and Tobacco mosaic virus. Biokemistri, Llorin, v. 16, p. $112-120,2004$

2. Dey, P.M.; Harborne, J.B. Plant Biochemistry. Academic Press, London, 1997. 554 p.

3. El-Hammady, M.; Shatla, M.N.; Girgis, A.N.; El-Halwagy, M.H
Virus diseases of some medicinal plants in Egypt. III. Effect of single and double infection with CMV and PVX on the alkaloids of Datura stramonium L. leaves. Acta Phytopatologica Academiae Scientiarum Hungaricae, Budapest, v. 17, p. 47-51, 1982 .

4. Harborne, J. B. Phytochemical methods. $3^{\text {rd }}$ Ed.. Chapman \& Hall, London, 1998. 302 p

5. Horwitz, H. Official Methods of Analysis of the Association of Official Agricultural Chemists. 8th ed. Ass Off. Agr. Chem., Washington, 1955, p. 144.

6. Hull, R. Matthews's plant virology. Academic Press, San Diego, 2002, p. 1001 .

7. Legrand, M.; Fritig, B.; Hirth, L. Enzymes of the phenylpropanoid pathway and the necrotic reaction of hypersensitive tobacco to tobacco mosaic virus. Phytochemistry, Oxford, v. 15, p. 1353-1359, 1976.

8. Nicholson, R.L. Phenolic compounds and their role in disease resistance. Annual Review of Phytopathology, Arkansas, v. 30, p. 369-383, 1992.

9. Nuhu, H.; Ghani, A. Alkaloid content of the leaves of three nigerian Datura species. Nigerian Journal of Natural Products and Medicine, Ile-Ife, v.6, p.15-18, 2002.

10. Phillips, R.; Henshaw, G.G. The regulation of synthesis of phenolics in stationary phase cell cultures of Acer pseudoplatanus L. Journal of Experimental Botany, Oxford UK, v. 35, p. 108 $114,1977$.

11. Rangaraju, R.; Chenulu, V.V. Effect of Solanum klasianum mosaic virus on certain growth characters and alkaloid content of its host. Acta Phytopatologica Academiae Scientiarum Hungaricae, Budapest, v. 10, p. 237-243, 1975.

12. Salazar, L.F. The economic impact of filamentous plant virusesSouth America. In: MILNE, R.G.(Ed.). The filamentous plant viruses. The plant viruses. v. IV, Plenum Press, New York, p.343-348, 1988 .

13. Schuster, G. Unttersuchungen über die auswirkungen non virusbefall auf den alkaloidgehalt von Datura stramonium L. var. stramonium. Phytopathologische Zeitschrift, Berlin, v. 131, p. $123-132,1958$

14. Uegaki, R.; Kubo, S.; Fujimori, T. Stress compounds in leaves of Nicotiana undulata induced by TMV inoculation. Phytochemistry, Oxford, v. 27, p. 365-368, 1988.

15. Wood, K.R. Pathophysiological alterations. In: MANDAHAR, C.L. (Ed.). Plant Viruses. v. II, CRC Press, Boca Raton, p. 2363, 1990 . 